\section{MODEL TARIKAN PERJALANAN PADA PUSAT PERBELANJAAN BERKONSEP MULTI ACTIVITY COMMERCIAL DI PUSAT KOTA SEMARANG}

\author{
Yudi Basuki , Sri Rahayu, Diva Khansa Gusanti \\ Departemen Perencanaan Wilayah dan Kota, \\ Fakultas Teknik, Universitas Diponegoro, Indonesia
}

Jurnal Pengembangan Kota (2020) Volume 8 No. 2 (212-220)

Tersedia online di:

http://ejournal2.undip.ac.id/index.php/jpk DOI: 10.14710/jpk.8.2.212-220

\begin{abstract}
Abstrak. Pusat perbelanjaan sebagai salah satu guna lahan pada aktivitas perdagangan dan jasa, memiliki intensitas permintaan perjalanan yang cukup tinggi untuk menarik pergerakan. Duta Pertiwi Mall (DP Mall) adalah pusat perbelanjaan berkonsep multi activity commercial yang terletak di pusat Kota Semarang dan berpotensi menarik pengunjung dalam jumlah yang tinggi. Diperlukan pemahaman antara karakteristik pusat perbelanjaan berkonsep multi activity commercial dengan tarikan pengunjung. Penelitian ini bertujuan untuk membuat model tarikan perjalanan pada DP Mall sebagai pusat perbelanjaan di pusat kota berkonsep multi activity commercial. Metode penelitian yang digunakan adalah trip rate, dan analisis regresi linier berganda. Data yang digunakan pada penelitian berupa identifikasi jenis dan luas aktivitas, serta penghitungan jumlah pengunjung DP Mall dan tiap jenis aktivitas pada jam puncak. Hasil penelitian ini adalah nilai trip rate total DP Mall sebesar 4,64 pengunjung per 1000 sq. $\mathrm{ft}$ GFA. Trip rate terbesar adalah pada aktivitas makan yaitu 44,8 pengunjung per $1000 \mathrm{sq} \mathrm{ft} \mathrm{GFA.} \mathrm{Meskipun} \mathrm{trip} \mathrm{rate}$ tersebesar adalah pada aktivitas makan, ternyata aktivitas yang paling berpengaruh pada tarikan DP Mall di jam puncak adalah aktivitas menonton. Hal ini ditunjukkan oleh model regresi dengan persamaan $Y=79+4,29 X_{3}$ dengan $X_{3}$ adalah jumlah pengunjung aktivitas menonton. Diharapkan dengan model ini dapat digunakan untuk mengantisipasi permasalahan transportasi akibat perkembangan guna lahan komersial khususnya pusat perbelanjaan dengan multi activity commercial.
\end{abstract}

Kata Kunci : Pusat Perbelanjaan; Multi Activity Commercial; Tarikan Perjalanan; Trip Rate; Model Regresi

[Title: Trip Attraction Model of Multi Activity Commercial Centre in The Center of Semarang City]. Shopping centers, as one of the commercial land use, have a high travel demand intensity to attract trips. Duta Pertiwi Mall (DP Mall) is a multi activity commercial shopping center located in the center of Semarang City and has the potential to attract a high number of visitors trip. It is necessary to understand the characteristics of a multi-activity commercial shopping center with the attraction of visitors. This study aims to create a trip attraction model at DP Mall as a shopping center in the city center with a multi activity commercial concept. The research method used is the trip rate and multiple linear regression analysis. The data in the research are the type and size of activities and the number of visitors to DP Mall for each type of activity during peak hours. The main result of this study is the trip rate of DP Mall as 4.64 visitors per 1000 sq. ft GFA. The biggest trip rate is on the activity of culinary which is 44.8 visitors per 1000 sq ft GFA. Although this activity gives the biggest trip rate according to the regression linear model the watching movie activity is the main factor of the trip rate DP Mall visitor in peak hour with the equation $Y=79+4.29 X 3$ where X3 is the number of visitors watching movie activities. It is hoped that this model can be used to anticipate transportation problems due to developments in commercial land use, especially in shopping centers with multi activity commercials.

Keyword: Shopping Centers, Multi Activity Commercials, Attraction Trips, Trip Rates, Regression Models

Cara Mengutip: Basuki, Yudi., Rahayu, Sri., \& Gusanti, Diva Khansa. (2020). Model Tarikan Perjalanan Pada Pusat Perbelanjaan Berkonsep Multi Activity Commercial di Pusat Kota Semarang. Jurnal Pengembangan Kota. Vol 8(2): 212220. DOI: $10.14710 /$ jpk.8.2.212-220

\section{PENDAHULUAN}

Kawasan perdagangan dan jasa merupakan guna lahan yang memiliki pengaruh atau dampak lalu lintas yang tinggi pada jaringan jalan di sekitarnya.
Sebagai kawasan perdagangan dan jasa, khususnya dengan lokasi yang strategis, pusat perdagangan dan jasa seringkali menimbulkan adanya kemacetan. Dengan demikian, beberapa penelitian tarikan dan bangkitan perjalanan dilakukan untuk 
menjadi bahan pertimbangan pengembangan suatu kawasan seperti kawasan perkantoran, pusat perbelanjaan, dan perumahan (Al Razib \& Rahman, 2017). Model transportasi dibuat untuk memprediksi pola pergerakan di masa depan yang mempengaruhi permintaan dan keputusan perencanaan (Heyns \& Van Jaarsveld, 2017). Salah satu model yang umum digunakan pada perencanaan transportasi adalah model matematika. Model matematika menggunakan persamaan atau fungsi matematika yang terdiri dari formulasi sederhana, model data seri, analisis regresi, model elastisitas, dan lain sebagainya (Heyns \& Van Jaarsveld, 2017; Tamin, 2008).

Penelitian tarikan perjalanan pada guna lahan perdagangan sudah mengalami perkembangan dan menjadi salah satu kunci penting dalam perencanaan transportasi (Al Razib \& Rahman, 2017; Vickerman \& Barmby, 1984). Berdasarkan penelitian terdahulu, perjalanan yang disebabkan oleh aktivitas komersial atau pusat perbelanjaan dinyatakan sebagai kategori perjalanan utama dari tarikan perjalanan setelah aktivitas pekerjaan (Sasidhar, Vineeth, \& Subbarao, 2016). Tarikan perjalanan tersebut bertujuan untuk memprediksi jumlah perjalanan yang ditarik oleh area perbelanjaan dan memprediksi bangkitan perjalanan yang dihasilkan oleh area tersebut perumahan (Al Razib \& Rahman, 2017). Namun rata-rata penelitian pemodelan tarikan perjalanan pusat perbelanjaan hanya menekankan pada skala ukuran dan single use retail tanpa memperhatikan multi fungsi penggunaan aktivitas lainnya (Sasidhar dkk., 2016). Umumnya, suatu tempat yang dapat menampung banyak kegiatan di dalamnya (multi activity commercial centre) cenderung diminati oleh para pengunjung (Farrag, El Sayed, \& Belk, 2010; Makgopa, 2016).

Multi activity commercial memiliki karakteristik yang sama dengan mixed-use development yaitu adanya penggabungan beberapa jenis aktivitas dalam satu bangunan komersial. Studi penelitian pada ITE (Institute of Transportation Engineers), sebuah institusi internasional yang sering mengeluarkan standar tentang tarikan dan bangkitan lalu lintas, menunjukkan bahwa trip rate pada penggunaan multi activity commercial lebih sedikit dibandingkan bangkitan perjalanan pada single use retail. Nilai tingkat perjalanan per unit pada supermarket yaitu 9,24 dan lebih besar dibandingkan dengan nilai tingkat perjalanan per unit pada pusat perbelanjaan dengan nilai 3,81 . Namun demikian, trip rate pada pusat perbelanjaan menurut Institute of Transportation Engineers tidak mempertimbangkan beberapa faktor di dalamnya, salah satunya pada jenis-jenis toko di dalamnya.

Timbulnya kemacetan di sekitar pusat perbelanjaan menjadi salah satu permasalahan yang mendorong perlu adanya pemodelan untuk memprediksi tarikan perjalanan pada kawasan pusat perbelanjaan modern dan mengetahui kontribusi perjalanan yang diakibatkan dari pembangunan retail modern tersebut. Menurut Zenina dan Borisov (2013), kalkulasi metode pada tarikan perjalanan untuk penggunaan lahan mixed use menggunakan metode analisis regresi. Analisis regresi pada model matematika paling tepat digunakan untuk memprediksi trip ends maupun trip volume (Heyns \& Van Jaarsveld, 2017). Metode analisis regresi merupakan metode analisis yang digunakan untuk mengetahui hubungan atau korelasi antar variabel independen dengan variabel dependen, dan diwujudkan dalam bentuk persamaan matematika. Analisis regresi terdiri dari dua jenis, yaitu analisis regresi linier dan analisis regresi multilinier. Meskipun sama-sama menggunakan analisis regresi, variabel independen yang digunakan pada tiap penelitian berbedabeda. Penggunaan variabel yang dikembangkan dengan beberapa penelitian menggunakan regresi berganda menunjukkan bahwa luas lantai terkait dengan daya tarik perjalanan (Sasidhar dkk., 2016). Variabel independen yang telah digunakan untuk pemodelan tarikan perjalanan meliputi trip rate, luas area parkir, luas lantai kasar, jumlah pegawai, jumlah toko, jumlah kendaraan, gender, dan lainnya. Maka dari itu, pemilihan variabel independen pada analisis regresi linier berganda untuk pemodelan tarikan perjalanan disesuaikan dengan karakteristik pusat perbelanjaan pada setiap lokasi penelitian. Pada proses perkembangannya, konsep perbelanjaan modern dengan menggabungkan beberapa aktivitas

\section{ISSN 2337-7062 @ 2020}

This is an open access article under the CC-BY-NC-ND license (http://creativecommons.org/licenses/by-nc-sa/4.0/). - lihat halaman depan (C 2020

*Email yudibasuki@yahoo.com

Diterima 2 Oktober 2020, disetujui 30 November 2020 
komersial juga sedang marak terjadi di perkotaan seperti juga di Semarang.

Salah satu pusat perbelanjaan modern di Kota Semarang, Duta Pertiwi Mall (DP Mall), termasuk dalam mixed use retail. Aktivitas yang ditunjang meliputi aktivitas perbelanjaan pada supermarket, aktivitas pelayanan jasa pada tempat makan, tempat bermain, dan tempat menonton. DP Mall adalah salah satu pusat perbelanjaan yang terletak di pusat kota Semarang. Keistimewaan DP Mall tidak hanya terletak di pusat kota atau segitiga emas Kota Semarang saja, namun juga karena telah mengalami perkembangan dari tiga aktivitas dengan skala yang masih kecil dan berkembang menjadi empat aktivitas. Awalnya, DP Mall hanya mendukung tiga aktivitas yang meliputi aktivitas perbelanjaan, aktivitas makan, dan aktivitas bermain. Aktivitas perbelanjaan sebelumnya terdiri dari supermarket dan beberapa kios kecil, kemudian aktivitas makan yang didukung oleh food court, dan wahana aktivitas bermain. Perkembangan berikutnya adalah adanya penambahan bioskop, khususnya jenis bioskop yang tidak dapat ditemukan di bioskop lain di Kota Semarang. Selain itu, DP Mall menjadi satu-satunya pusat perbelanjaan di Kota Semarang yang memiliki tempat karaoke dan brand fashion ternama. Dengan demikian, perlu adanya pemodelan untuk memprediksi tarikan perjalanan pada retail modern dengan multi fungsi penggunaan aktivitas. Selain itu, analisis pemodelan dapat berguna untuk penelitian pada masa depan dan mempermudah dalam keakuratan prediksi tingkat perjalanan dan perencanaan fasilitas transportasi (Jayasinghe, Sano, \& Rattanaporn, 2017).

\section{METODE PENELITIAN}

Metode yang digunakan pada penelitian ini terdiri dari dua jenis, yaitu penghitungan trip rate, dan pembuatan model regresi linier berganda.

Penghitungan trip rate pada penelitian ini didapatkan dari jumlah pengunjung dalam suatu luasan tertentu (Al Razib \& Rahman, 2017). Penghitungan trip rate juga dapat dilakukan pada tiap aktivitas di suatu pusat perbelanjaan. Sasidhar dkk. (2016) mengungkapkan bahwa semakin besar luas lantai kotor suatu area komersial, maka semakin besar pula jumlah tarikan pengunjungnya. Dengan mengetahui trip rate suatu aktivitas, dapat digunakan untuk memperkirakan besarnya jumlah pengunjung berdasarkan perubahan luasan aktivitas. Oleh karena itu, trip rate yang dikalkulasikan pada penelitian dapat berguna untuk mengatur sistem jaringan transportasi di kawasan sekitar pusat perbelanjaan baru.

Dalam penelitian ini, trip rate dilakukan pada keseluruhan jumlah pengunjung DP Mall dengan jumlah pengunjung pada tiap aktivitas di DP Mall secara bersamaan pada jam puncak. Perhitungan trip rate didapatkan dari jumlah pengunjung per satuan waktu dibagi luas tiap aktivitas dengan satuan GFA (Gross Floor Area) agar dapat dibandingkan dengan trip rate aktivitas sejenis pada International Transportation Engineer (ITE).

Analisis regresi linier berganda digunakan untuk menghasilkan pemodelan tarikan perjalanan DP Mall. Pada model regresi ini yang menjadi variabel terikat atau dependen adalah jumlah pengunjung dari DP Mall. Kemudian yang menjadi variabel bebas atau independen adalah jumlah pengunjung dari masing-masing aktivitas. Persamaan model regresi ini dapat dituliskan seperti berikut.

$Y=A+B_{1} X_{1}+B_{2} X_{2}+B_{3} X_{3}+B_{4} X_{4}$

Keterangan:

$\mathrm{Y}=$ jumlah pengunjung DP Mall

$A=$ konstanta regresi

$\mathrm{B}_{1} \ldots \mathrm{B}_{4}=$ koefisiensi regresi

$\mathrm{X}_{1}=$ jumlah pengunjung aktivitas belanja

$\mathrm{X}_{2}=$ jumlah pengunjung aktivitas kuliner

$\mathrm{X}_{3}=$ jumlah pengunjung aktivitas menonton

$X_{4}=$ jumlah pengunjung aktivitas bermain

Setelah membuat pemodelan regresi tersebut, data yang didapatkan akan diuji melalui koefisian determinan (R2), Uji $t$, dan Uji F. Hal tersebut dilakukan untuk mendapatkan data yang valid dan untuk mengetahui pengaruh variabel independen terhadap variabel dependen yang digunakan pada pemodelan (Widarjono, 2018). Dengan model ini diharapkan dapat menjelaskan jenis aktivitas apa yang berpengaruh pada tarikan perjalanan pusat perbelanjaan berkonsep multi activity commercial. Dari model ini juga, diharapkan dapat digunakan untuk memprediksikan tarikan perjalanan DP Mall ketika luasan aktivitas yang berpengaruh berubah berdasarkan trip rate nya. 


\section{HASIL DAN PEMBAHASAN}

Duta Pertiwi Mall (DP Mall) merupakan suatu pusat perbelanjaan yang berlokasi pusat kota di Jalan Pemuda Nomor 150, Kelurahan Sekayu, Kecamatan Semarang Tengah, Kota Semarang. DP Mall termasuk dalam pembagian kawasan di Bagian Wilayah Kota I (BWK I) dengan fungsi kawasan adalah perkantoran, perdagangan dan jasa. DP Mall ini berada di yang termasuk di dalam kawasan segitiga emas Kota Semarang (ruas Jalan Gajahmada, Jalan Pemuda, dan Jalam Pandanaran). Jalan Pemuda sendiri terklasifikasi sebagai jalan kolektor sekunder menurut RTRW Kota Semarang Tahun 2011-2031. Lokasi DP Mall dapat dilihat pada Gambar 1.

DP Mall Semarang merupakan pusat perbelanjaan yang mulai beroperasi pada tahun 2007 dan dikelola oleh PT. Wijaya Pratama Raya yang termasuk dalam pengelolaan Sinarmas Group. Pada awalnya, DP Mall hanya menyediakan satu supermarket, kios makanan, dan kios tempat bermain, serta beberapa kios/tenants pada varian fashion, gadget, dan kesehatan. Namun, mulai tahun 2017, bioskop mulai dibangun di gedung lantai dua DP Mall. Ciri khas DP Mall sendiri tidak hanya berdasarkan letaknya di pusat kota, tetapi juga karena mengalami perubahan dari tiga aktivitas dengan skala yang masih kecil dan berkembang menjadi empat aktivitas.

Bangunan DP Mall berdiri di atas tanah seluas 2,6 hektar yang terdiri dari satu supermarket, 90 kios/toko, dan tiga tempat hiburan. Didukung dengan konsep millennial dengan gaya industrial, menjadikan DP Mall sebagai pusat perbelanjaan modern yang banyak diminati oleh masyarakat. DP Mall juga mendukung banyak aktivitas yang ditunjang oleh adanya 1 supermarket, 60 kios/toko makanan, 8 kios kesehatan dan kecantikan, 4 kios olahraga, 5 kios gadget, 10 kios fashion, 2 kios tempat bermain, 1 bioskop, dan 1 tempat karaoke. Oleh karena itu, DP Mall menjadi salah satu destinasi perbelanjaan dan bermain bagi banyak masyarakat di Kota Semarang. DP Mall memiliki 4 lantai area, yaitu lantai bawah, lantai satu, lantai dua, dan lantai tiga. Aktivitas yang terdapat di lantai satu adalah aktivitas pelayanan jasa pada tempat makan dan perbelanjaan, aktivitas berbelanja pada lantai dua, dan pada lantai tiga menunjang aktivitas pada tempat makan, tempat bermain, dan tempat menonton. Berdasarkan hasil observasi, perhitungan luas untuk aktivitas belanja $14.456 \mathrm{~m}^{2}$, aktivitas makan $2.870 \mathrm{~m}^{2}$, aktivitas menonton $3.383 \mathrm{~m}^{2}$, aktivitas bermain $1.939 \mathrm{~m}^{2}$ dan luas total DP Mall $39.382 \mathrm{~m}^{2}$.

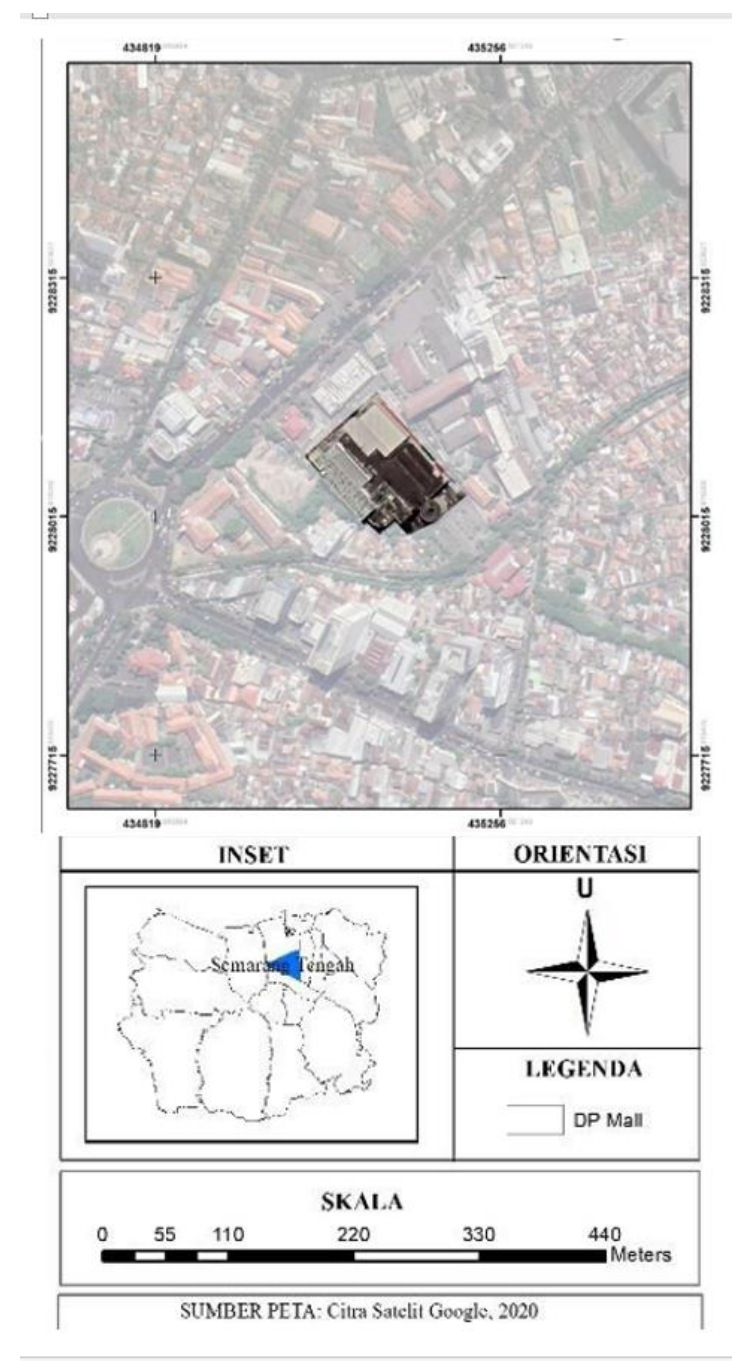

Gambar 1. Peta Lokasi DP Mall

Penghitungan jumlah pengunjung dilakukan pada saat jam puncak (peak hour) DP Mall. Penelitian ini dilakukan pada Hari Sabtu dengan jam puncak dari pukul 19.00 hingga 20.00 WIB berdasarkan hari dan jam pengunjung terbanyak dengan rentang penghitungan 10 menit tiap segmen penghitungan pengunjung seperti terlihat pada Tabel 1. 
Tabel 1. Jumlah Pengunjung DP Mall pada Jam Puncak

\begin{tabular}{|c|c|c|c|c|c|}
\hline $\begin{array}{c}\text { Rentang } \\
\text { Pengamatan }\end{array}$ & $\begin{array}{c}\text { Jumlah } \\
\text { Pengunjung } \\
\text { DP Mall (orang) }\end{array}$ & $\begin{array}{c}\text { Jumlah } \\
\text { Pengunjung } \\
\text { aktivitas } \\
\text { Belanja (orang) }\end{array}$ & $\begin{array}{c}\text { Jumlah Pengunjung } \\
\text { aktivitas } \\
\text { Makan } \\
\text { (orang) }\end{array}$ & $\begin{array}{l}\text { Jumlah } \\
\text { Pengunjung } \\
\text { aktivitas } \\
\text { Menonton } \\
\text { (orang) }\end{array}$ & $\begin{array}{l}\text { Jumlah } \\
\text { Pengunjung } \\
\text { aktivitas } \\
\text { Bermain (orang) }\end{array}$ \\
\hline $19.00-19.10$ & 344,00 & 166,00 & 257,00 & 66,00 & 42,00 \\
\hline $19.10-19.20$ & 332,00 & 82,00 & 240,00 & 54,00 & 32,00 \\
\hline $19.20-19.30$ & 318,00 & 106,00 & 223,00 & 49,00 & 39,00 \\
\hline $19.30-19.40$ & 195,00 & 114,00 & 197,00 & 38,00 & 41,00 \\
\hline $19.40-19.50$ & 217,00 & 122,00 & 251,00 & 29,00 & 45,00 \\
\hline $19.50-20.00$ & 219,00 & 102,00 & 216,00 & 32,00 & 52,00 \\
\hline Total & 1625,00 & 692,00 & 1384,00 & 268,00 & 251,00 \\
\hline
\end{tabular}

Guna mengetahui tarikan perjalanan yang disebabkan oleh pusat perbelanjaan DP Mall, penelitian menggunakan analisis trip rate. Analisis dengan trip rate umumnya digunakan untuk mengestimasi tarikan perjalanan pada pusat perbelanjaan yang dilakukan pada suatu jam puncak (Uddin, Hasan, Ahmed, Das, Uddin, \& Hasan, 2012). Trip rate dihitung berdasarkan perhitungan jumlah pengunjung dibagi dengan luas selama jam puncak. Trip rate ini memiliki satuan $\mathrm{m}^{2}$ yang dikonversikan menjadi 1000 square feet Gross Floor Area dengan pengalian nilai 10,76. Berdasarkan hasil pengamatan yang telah dilakukan pada waktu puncak mingguan yaitu Hari Sabtu, 29 Februari 2020, didapatkan trip rate berdasarkan adanya data jumlah pengunjung serta luas DP Mall seperti pada Tabel 2.

Tabel 2. Trip Rate DP Mall

\begin{tabular}{|c|c|c|c|c|c|c|}
\hline Aktivitas & $\begin{array}{c}\text { Jumlah } \\
\text { Pengunjung }\end{array}$ & $\begin{array}{l}\text { Luas (meter } \\
\text { persegi) }\end{array}$ & $\begin{array}{c}\text { Trip Rate } \\
\text { (meter } \\
\text { persegi) }\end{array}$ & $\begin{array}{l}\text { Luas } \\
\text { (sq. ft) }\end{array}$ & $\begin{array}{c}\text { Luas } \\
\text { (per } 1000 \text { sq. ft) }\end{array}$ & $\begin{array}{c}\text { Trip Rate } \\
\text { (1000 } \\
\text { sq. ft GFA) }\end{array}$ \\
\hline Belanja & 3.113 & 14.456 & 0,215 & 155.609 & 155,61 & 20,11 \\
\hline Makan & 1.384 & 2.870 & 0,482 & 30.892 & 30,89 & 44,8 \\
\hline Menonton & 268 & $3.383,5$ & 0,079 & 36.419 & 36,42 & 7,36 \\
\hline Bermain & 251 & $1.939,25$ & 0,129 & 20.878 & 20,87 & 12,02 \\
\hline DP Mall & 1.967 & 39.382 & 0,050 & $423.906,5$ & 423,91 & 4,64 \\
\hline
\end{tabular}

Berdasarkan Tabel 2 di atas, dapat diketahui bahwa jumlah pengunjung total saat jam puncak mencapai 1.967 pengunjung dengan luas 39.382 $\mathrm{m}^{2}$. Menurut Al Razib dan Rahman (2017)Al Razib (2017), penelitian terhadap enam pusat perbelanjaan menunjukkan bahwa jangkauan atau range trip rate pada pusat perbelanjaan memiliki nilai di antara 5 sampai 13 pengunjung per 1000 sq. ft per jam. Hal tersebut menunjukkan bahwa trip rate pada DP Mall untuk setiap $100 \mathrm{~m}^{2}$ luasan di DP Mall adalah 5 orang atau setara dengan 4,64 yang dibulatkan menjadi 5 orang per 1000 sq. ft GFA sesuai dengan nilai range dari penelitian sebelumnya. Apabila dibandingkan dengan klasifikasi Shopping Center menurut ITE, trip rate untuk lokasi perkotaan yaitu 4,92 orang per 1000 sq. ft GFA. Angka tersebut sedikit lebih besar dibandingkan trip rate di DP Mall dengan nilai trip rate sebesar 4,64 orang per 1000 sq. ft GFA. Jika dibandingkan dengan pusat perbelanjaan di nonpusat kota di Kota Semarang, DP Mall memiliki nilai trip rate yang lebih kecil. Dalam penelitiannya, Basuki, Rahayu, dan Gritanarum (2019) menunjukkan bahwa trip rate pada pusat perbelanjaan dengan konsep multi activity di non-pusat kota memiliki nilai sebesar 0,057 orang $/ \mathrm{m}^{2}$ yang berarti bahwa terdapat 6 orang untuk setiap luasan $100 \mathrm{~m}^{2}$. Dari perbandingan ini maka trip rate DP Mall sebagai pusat perbelanjaan multi activity di pusat kota lebih kecil. 
Trip rate tiap jenis aktivitas didapatkan berdasarkan jumlah pengunjung per luasan tiap aktivitas di DP Mall. Trip rate dihitung berdasarkan perhitungan jumlah pengunjung dibagi dengan luas selama jam puncak. Trip rate ini memiliki satuan $\mathrm{m}^{2}$ yang dikonversikan menjadi 1000 square feet Gross Floor Area. Analisis digunakan untuk empat jenis aktivitas yang terdiri dari aktivitas perbelanjaan, aktivitas makan, aktivitas menonton, dan aktivitas bermain (lihat Tabel 2). Menurut trip rate berdasarkan ITE, terdapat tiga jenis karakteristik aktivitas makan pada DP Mall yang dapat terklasifikasi sebagai high turnover sit-down restaurant, drinking place, dan food court. Apabila dihitung, trip rate drinking place pada DP Mall sebesar 44,48 orang per 1000 sq. ft GFA, jauh lebih besar dibandingkan standar di ITE (11,36 per 1000 sq. ft). Pada aktivitas perbelanjaan, menurut klasifikasi pada ITE, Supermarket memiliki nilai trip rate 9,24 orang per 1000 sq. $\mathrm{ft}$., sedangkan pada DP Mall adalah 20,11 orang per 1000 sq. ft.

Aktivitas bermain sebesar 12 orang per luasan $1000 \mathrm{sq} \mathrm{ft}$., di mana jauh lebih besar dari besaran Multi Purpose Recreational Facility di ITE yaitu 5,77 per acre $(1$ acre $=43.560 \mathrm{sq} \mathrm{ft}=43,56$ per $1000 \mathrm{sq}$ $\mathrm{ft}$ ) atau 0,13 orang per $1000 \mathrm{sq} \mathrm{ft}$. Apabila trip rate aktivitas menonton pada DP Mall dibandingkan dengan Movie Theater pada ITE, maka nilai trip rate di DP Mall 9,56 orang per 1000 sq. ft masih lebih besar dibandingkan nilai trip rate ITE 6,17 orang per 1000 sq. ft.

Model tarikan perjalanan DP Mall didapatkan berdasarkan analisis dari regresi linier dari jam puncak, yaitu pukul 19.00 hingga 20.00 dengan segmen/interval waktu per 10 menit. Pada pemodelan ini, $y$ merupakan jumlah pengunjung DP Mall yang berperan sebagai variabel dependen. Kemudian untuk variabel independen terdiri dari empat, yaitu $x_{1}$ merupakan jumlah pengunjung dari aktivitas perbelanjaan, $x_{2}$ merupakan jumlah pengunjung dari aktivitas makan, $x_{3}$ merupakan jumlah pengunjung dari aktivitas menonton, dan $x_{4}$ yang merupakan jumlah pengunjung dari aktivitas bermain. Model dilakukan dengan metode stepwise dan menghasilkan persamaan $Y=79+$ $4,29 X_{3}$. Arti dari persamaan ini adalah bahwa jenis aktivitas yang mempengaruhi jumlah tarikan pengunjung ke DP Mall pada jam puncak adalah aktivitas menonton. Persamaan regresi yang dihasilkan memiliki nilai konstanta sebesar 79 , hal tersebut berarti bahwa masih terdapat variabel lain diluar variabel $X 3$ yang mempengaruhi tarikan pengunjung DP Mall.

Uji $\mathrm{F}$ digunakan untuk menunjukkan apakah terdapat pengaruh dari semua variabel independen terhadap variabel dependen. Uji $F$ membandingkan $F_{\text {hitung }}$ dengan nilai $F_{\text {tabel }}$ atau dapat dengan menggunakan nilai signifikan dibandingkan dengan taraf nyata senilai $5 \%$ atau 0,05 . Pada penelitian ini, terdapat hipotesis adanya hubungan antara $x$ dan $y$. Hasil pengolahan data menunjukkan nilai $F=7.386,764$ dan sig $=0,009$. Nilai sig 0,009 $<0,05$, sehingga hipotesis diterima. Maka persamaan yang dihasilkan menunjukkan bahwa model layak dan variabel $x$ secara keseluruhan berpengaruh terhadap variabel $y$ sehingga analisis dapat dilanjutkan untuk mengetahui besarnya pengaruh variabel independen secara simultan dengan koefisien determinasi.

Model ini memiliki koefisien determinasi yang diukur dengan nilai R-Square $\left(R^{2}\right)$ sebesar 0,83 . Hal tersebut berarti bahwa model dapat mewakili peristiwa nyatanya karena mendekai nilai 1,00 . Menurut Sugiyono (2007), nilai koefisien korelasi 1,00 menunjukkan bahwa terdapat hubungan yang sangat kuat pada variabel yang digunakan.

Cara untuk mengetahui pengaruh variabel independen terhadap variabel dependen secara terpisah dapat dilakukan dengan melakukan uji $t$ pada tabel coefficient. Apabila nilai signifikan menunjukkan nilai kurang dari 0,05 , hal tersebut berarti bahwa suatu variabel independen secara individu berpengaruh terhadap variabel dependen. Pada model yang telah dihasilkan, dapat diketahui bahwa nilai signifikan dari variabel $x_{3}$ adalah 4.309 dengan signifikansi 0,013. Hal tersebut berarti bahwa variabel independen secara terpisah mempengaruhi variabel dependen. Berdasarkan tabel coefficient, nilai koefisien positif menunjukkan bahwa terdapat pengaruh searah dari $x$ terhadap $y$, sedangkan nilai negatif berarti bahwa pengaruh variabel independen tersebut berbanding terbalik dengan y. Dari persamaan di atas dapat diketahui bahwa variabel yang 
mempengaruhi jumlah kunjungan adalah aktivitas menonton dengan koefisien 4,29. Nilai ini memiliki arti apabila terjadi penambahan jumlah pengunjung aktivitas menonton maka akan menyebabkan pertambahan tarikan perjalanan DP Mall sebanyak 4,29 kali. Penambahan pengunjung aktivitas menonton dapat diperkirakan bila terjadi penambahan luas aktivitas menonton dengan cara mengalikan luasan dengan trip rate nya.

\section{KESIMPULAN}

Duta Pertiwi Mall merupakan salah satu pusat perbelanjaan yang mampu menunjang empat aktivitas di dalamnya. Sistem aktivitas yang berupa pusat perbelanjaan pada kawasan perdagangan menyebabkan tarikan perjalanan sebagai bentuk permintaan pelaku perjalanan. Pada pusat perbelanjaan dengan konsep multi activity, tarikan perjalanan yang dihasilkan berbeda-beda dari setiap aktivitas dengan tarikan tertinggi pada aktivitas makan, kemudian aktivitas berbelanja, aktivitas menonton dan aktivitas bermain. Dari keempat aktivitas tersebut berdasarkan model regresi, aktivitas menonton merupakan aktivitas yang mempengaruhi besaran tarikan pengunjung DP Mall pada jam puncak. Keunikan jenis layanan dan jadwal operasi aktivitas menonton di DP Mall menjadi penyebab tarikan pengunjung pada jam puncak. Hal ini akan mengakibatkan bertambahnya tarikan pengunjung mana kala terjadi pertambahan luasan aktivitas menonton. Model regresi ini dapat digunakan untuk memperkirakan jumlah tarikan pengunjung pada DP Mall berdasarkan perubahan luas aktivitas menonton sehingga permasalahan transportasi akibat tarikan pengunjung dapat diantisipasi.

\section{DAFTAR PUSTAKA}

Al Razib, M. S., \& Rahman, F. I. (2017). Determination of Trip Attraction Rates of Shopping Centers in Uttara Area, Dhaka. American Journal of Management Science and Engineering, 2(5), 150-155. doi: 10.11648/j.ajmse.20170205.19

Basuki, Y., Rahayu, S., \& Gritanarum, M. (2019). Trip Rate dan Pola Pergerakan Pada Transmart Setiabudi Semarang sebagai Salah Satu Pusat Perbelanjaan Berkonsep Multi-
Aktivitas. Jurnal Pengembangan Kota, 7(1), 77-82. Doi: 10.14710/jpk.7.1.77-82

Farrag, D. A., El Sayed, I. M., \& Belk, R. W. (2010). Mall Shopping Motives and Activities: A Multimethod Approach. Journal of International Consumer Marketing, 22(2), 95-115. Doi: 10.1080/08961530903476113

Heyns, W., \& Van Jaarsveld, S. (2017). Transportation modelling in practice: connecting basic theory to practice. Transportation, Land Use and Integration: Perspectives for Developing Countries, WIT Transactions on State of the Art in Science and Engineering, 100, 3-27. Doi: http://dx.doi.org/10.2495/978- 1-78466 233-2/001

Institute of Transportation Engineers. Trip Generation Manual, 10th Edition. Retrieved from https://www.troutdaleoregon.gov.

Jayasinghe, A., Sano, K., \& Rattanaporn, K. (2017). Application for Developing Countries: Estimating Trip Attraction in Urban Zones Based on Centrality. Journal of Traffic and Transportation Engineering (English Edition), 4(5), 464-476. Doi: https://doi.org/10.1016/j.jtte.2017.05.011

Makgopa, S. (2016). Determining Consumers' Reasons for Visiting Shopping Malls. Innovative Marketing, 12(2), 22-27. Doi: http://dx.doi.org/10.21511/im.12(2).2016. 03

Sasidhar, K., Vineeth, Y., \& Subbarao, S. (2016). Trip Attraction Rates of Commercial Land Use: A Case Study. Indian Journal of Science and Technology, 9(30). Doi: http://dx.doi.org/10.17485/IJST/2016/V9I3 $0 / 99245$

Sugiyono, S. (2007). Metode Penelitian Kualitatif Kuantitatif dan $R \& D$. Bandung: Alfabeta.

Tamin, O. Z. (2008). Perencanaan dan Pemodelan Transportasi Edisi Kedua. Bandung: Institut Teknologi Bandung.

Uddin, M., Hasan, M. R., Ahmed, I., Das, P., Uddin, M. A., \& Hasan, T. (2012). A Comprehensive Study on Trip Attraction Rates of Shopping Centers in Dhanmondi Area. International Journal of Civil \& Environmental Engineering IJCEE-IJENS, 12(4), 12-16.

Vickerman, R., \& Barmby, T. (1984). The Structure of Shopping Travel: Some Developments of 
The Trip Generation Model. Journal of Transport Economics and Policy, 109-121.

Widarjono, A. (2018). Analisis Regresi dengan SPSS. Yogyakarta: UPP STIM YKPN.

Zenina, N., \& Borisov, A. (2013). Regression Analysis for Transport Trip Generation Evaluation. Information Technology and Management Science, 16(1), 89-94. Doi: http://dx.doi.org/10.2478/ITMS-2013-

0014 